\title{
The Role of Human Resource Management in Developing Tourism Industry in Sri Lanka: A proposed conceptual framework
}

\author{
Aruna S. Gamage \\ Senior Lecturer \\ University of Sri Jayewardenepura
}

\begin{abstract}
Tourism is a fast growing industry in Sri Lanka. Since gaining independence from the British in 1948, Sri Lanka has continued to attract foreign investors and tourists to the island. However it is the post war period that the sector has featured prominently a rapid growth. The arrival of tourists increased rapidly and passed the elusive one million mark in 2012 and increased further in 2014 and 2015. Consequently, the tourist earnings also increased and now the sector occupies the position as the third largest foreign exchange earner to the country after overseas remittances and textiles and apparel exports. It is expected to increase the number of arrivals up to 2.6 million by 2020 .
\end{abstract}

However, as a growing sector in the economy this sector faces several challenges and Human Resource Crises have been the top among others. The shortage of well-trained tourism personnel coupled with high rate of turnover continued to be a major issue for the industry with the situation worsening with many new hotels coming up in the country and absorbing the existing experienced personnel.

Therefore, the broad objective of this study is to examine the role of Human Resource Management in finding suitable solutions to assist the industry to deal with HR issues successfully. In fact, as the first phase, this study attempts to develop a research model for action. Specifically, this study is designed to examine the role of Human Resource Management (HRM) practices in developing tourism sector in Sri Lanka and to propose a theoretical model that can be used to embark on a study to measure the real impact of HRM on the performance of tourism sector in Sri Lanka. The proposed model suggests a significant correlation that exists between HRM practices and firm performance in tourism sector. Further, the model will help better understand the missing link through which HRM practices will make the impact on firm performance in tourism sector in Sri Lanka.

Key Words: human resource management, tourism sector, HR outcomes, operational outcomes, financial outcomes.

\section{Introduction}

Tourism sector is playing a pivotal role in Sri Lankan economy. Now, this is the third largest foreign earner to the country (US \$ 1.7 billion) after oversees remittance (US \$ 6.4 billion) and textile \& apparels (US \$ 4.5 billion). The direct contribution of Travel \& Tourism to GDP in 2014 was LKR462.1 billion which is 4.8 percent of GDP (WTTC, 2015).This primarily reflects the economic activity generated by industries such as hotels, travel agents, airlines and other passenger transportation services. But it also includes, for example, the activities of the restaurant and leisure industries directly supported by tourists. The direct contribution of Travel 
\& Tourism to GDP is expected to grow by 6.1 percent to LKR842.5bn (6.1 percent of GDP) by 2025 (WTTC, 2015). Travel \& Tourism generated 286,000 jobs directly in 2013 (3.5 percent of total employment). This includes employment by hotels, travel agents, airlines and other passenger transportation services. It also includes, for example, the activities of the restaurant and leisure industries directly supported by tourists. By 2024, Travel \& Tourism will account for 360,000 jobs directly, an increase of 2.5 percent over the next ten years. Travel \& Tourism is forecast to support 804,000 jobs, 9.5 percent of total employment (WTTC, 2014).Visitor exports are a key component of the direct contribution of Travel \& Tourism. In 2013, Sri Lanka generated LKR254.1bn in visitor exports. By 2024, international tourist arrivals are forecast to total 2,571,000, generating expenditure of LKR469.0bn, an increase of 6.1 percent pa (WTTC, 2014).

As a growing sector in the economy it faces several challenges. Among them human resource issue is one of the critical challenges which has been highlighted by various commentators from time to time (Kelegama, 2014). According to Kelegama (2014), the number of total hotel rooms will increase to a level above 40,000 from the current 26,700 by 2016 . This will be a result of the number of hotels increasing by 75 in the formal sector and an unknown number in the informal sector. In this context, the question arises as to whether the human resources are adequate to meet this increase in hotels.

The shortage of well-trained tourism personnel continued to be a major issue for the industry with the situation worsening with many new hotels coming up in the country and absorbing the existing experienced personnel. This matter has been talked about at great length, and many tourism professionals have brought this up at many forums."While everyone is scurrying around trying to build and develop infrastructure and hotel rooms, the critical HR factor is a hidden issue, which will soon mushroom into a big issue in the near future, if not addressed in a strategic and holistic manner immediately"(Srilal,2014).

According to the Capital alliance (2014) 9,000 direct employees may be needed per annum for the hotel sector vs. the current 1,500 yearly output of industry graduates. There are moves by the Sri Lanka Institute of Tourism and Hotel Management (SLITHM) to forge partnerships with a foreign tourism educational body, to revamp their operations. This is indeed a very good initiative, but still remains the fact that SLITHM alone cannot produce Sri Lanka tourism industry's entire people requirement. It is up to the private sector tourism bodies (Ceylon Hotel School Graduates Association, THASL) to take the initiative to draw up a strategic master plan on how this problem should be addressed, and initiate a private sector/public sector partnership urgently.

The Sri Lanka Institute of Tourism and Hotel Management is bringing out close to 4,000 trained personnel per annum. Some of the Universities like Sabaragamuwa and Uva-Wellassa also produce 50 to 150 tourism trained graduates per annum. Apart from these, the existing private colleges in tourism also bring out some trained personnel although one cannot be sure about the quality of this training. Nevertheless, all these trained outputs will not be adequate to meet the expansion and growth of hotels. Moreover, the quality of output, especially the proficiency in English and some other key languages, does not appear to receive much attention in the current training programs. Thus, the human resource constraint remains a major challenge the industry 
will face in the coming years which both the industry and the government have to immediately address.

However, there is a dearth of information regarding the human resource issues in tourism industry and this study aims at initiating a comprehensive study to understand the impact of human resource management on the achievement of business performance of firms in tourism industry. This will help examine the role of human resource management practices in order to find suitable solutions to assist the companies in the tourism industry to survive and achieve expected goals thereby keeping tourism industry flourishing in Sri Lanka.

\section{Background of the Problem}

Although Sri Lanka has high growth potentials to develop tourism sector, human resource issues such as lack of skilled and semi-skilled workers, high rate of employee turnover etc. will hinder the progress of the sector. These issues can be mainly attributed to the lack of proper human resource management system within firms operating in the industry. Hospitality industry is considered a sub category within the services industry and has experienced significant growth with expanding global economy and positive changes pertaining to travel and hospitality industry in global environment. Further, services industry is widely accepted to be driven by customer satisfaction and therefore human resources are essential component of service delivery (Shamali and Samarakoon, 2010).

Human resource management is the effective and efficient utilization of human resources in order to achieve goals of an organization (Opatha, 2009). The generic purpose of Human Resource Management (HRM)is to generate and retain an appropriate and contented workforce that gives maximum contribution to the organizational success (Opatha, 2009). Therefore, a highly qualified, motivated and happy workforce is the main factor for the success of any organization. On one hand, effective HRM system helps organization attract and hire suitably qualified people and keep their knowledge, skills and attitudes updated. Therefore, they are capable of performing what they are supposed to perform in the organization. On the other hand, effective HRM system helps the organization retain most appropriate and contented workforce with the organization. It means that HRM system helps keep employees motivated. Motivated workforce is a happy workforce. This happy workforce will help organization achieve its desired objectives. For example, if the work force is happy, they are likely to give their maximum contribution to the organization by means of producing quality products or giving quality service.

HRM is the human side of the organizational management. It is mostly responsible for the attraction, selection, training, assessment, and rewarding of employees for getting maximum contribution toward the organizational success. Stone (2005) defined human resource management as productive use of people in achieving the organization's strategic business objectives and the satisfaction of individual employees. This definition clearly indicates that the organizations' objectives are dependent on their work force productivity. The effective use of HRM practices is able to link these practices with organization's goals and objectives. In order to accurately measure "human resource practices", a number of HR functions may need to be evaluated. The importance of these practices may differ from firm to firm. One of the most comprehensive and widely used measures for human resource practice was presented by Dessler (2008) and Fisher et al. (2006). In their studies, human resource management practices are 
characterized as multidimensional, and it has four major facets namely; staffing, training and development, employee performance evaluation, and compensation of employees.

Proper management of a company's human resources is the key to business survival in today's world. The organizational effectiveness of the firm (Huselid, 1995; Terpstra and Rozell, 1993) and its ability to create a sustainable competitive advantage (Prahalad,1983; Pfeffer, 1994) can hinge upon whether HRM practices are properly thought out and successfully implemented. The human potentials in a company are generally much more difficult for competitors to duplicate than the plant, equipment or even products that a company produces (Flanagan and Despanade, 1996). Consequently, the nature and wellbeing of a company's employees can become its main strength in carving out a profitable existence in the industry. Research indicates that inadequate and insufficient management of employees has resulted in low productivity and high turnover rates (Mathis and Jackson, 1991) and is one of the leading causes of business failures (McEvoy, 1984).

Understanding the relationship between HRM and business performance is one of the longstanding goals of macro HRM research. Indeed, Becker and Huselid (1998) considered this relationship as one of the essential pursuits of strategic HRM research. Strategic HRM research suggests that different types of outcomes may not necessarily have equivalent relationships with HR practices (Deleryand Shaw, 2001; Guest, 1997; Lepak, Liao, Chung, and Harden, 2006). Moreover, it is commonly asserted that HRM may influence the three types of organizational outcomes in sequence. For example, HR practices are expected to first influence HR outcomes (e.g., employee skills and motivation), which are proximal and the least likely to be contaminated by factors beyond HR practices. HR outcomes, in turn, may mediate the influence of HR practices on productivity, quality, service, safety, innovation, and other operational outcomes, which further affect financial outcomes.

\section{HRM Practices and Business Performance}

Business performance is viewed as multidimensional. Drawing on Dyer and Reeves's (1995) work, researchers in strategic HRM have categorized business performance into three primary groups related to HRM: HR outcomes, operational outcomes, and financial outcomes. $H R$ outcomes refer to those most directly related to HRM in an organization, such as employee skills and abilities, employee attitudes and behaviors, and turnover. Some of HRM outcomes commonly identified in HRM literature are listed in Table 1. HRM practices that put into practice in a firm will generate some or all of listed HRM outcomes at varying degrees. Operational outcomes are those related to the goals of an organizational operation, including productivity, product or service quality, new product development or innovation, and customer satisfaction. Financial outcomes reflect the fulfillment of the economic goals of organizations. Typical financial outcomes include growth in sales, growth in profits, return on invested capital, and return on assets (Jiang and Lepak, 2012). 


\section{Table 1: POSSIBLE HR OUTCOMES}

\begin{tabular}{l|l}
\hline Occupational safety of employees & Work efforts of employees \\
\hline Job satisfaction of employees & Cooperation of employees \\
\hline Employee commitment & Job involvement \\
\hline $\begin{array}{l}\text { Attitude of employees } \\
\text { Employee trust }\end{array}$ & Organizational citizenship behavior \\
\hline Less employee conflicts & Less absenteeism of employees \\
\hline $\begin{array}{l}\text { Employee loyalty } \\
\text { Source: Compiled by the Author based on the original article written by } \\
\text { Christopher J. C., Jeff E., and Mathew A. (2005) }\end{array}$
\end{tabular}

\section{Linking HRM to Business Performance}

This section first attempts to presents theories behind the proposed model of HRM practices contributing to business performance mediated by HR outcomes such as development of employee abilities, motivation, and opportunities to perform. There are many theories surrounding the concept of HRM which are useful for the study. Specifically, human capital theory, resource-based theory, and behavioral perspective will be discussed here. Then, based on human capital theory, resource based theory and behavioural perspective it continues discussing Ability-Motivation-Opportunity (AMO) model to construct a new model that is supposed to be fit for the tourism sector in Sri Lanka.

\section{Human Capital Theory}

Gary Becker's (1964) human capital theory recognizes that differential in education, training, and experience levels produce differential costs/earnings in many different labor markets. Wage levels are directly related to the profitability of the products in those markets and to the level of skills, which are developed through training and experience in order to produce those products. Training can be seen as an investment in human capital and the decision to undergo training and acquire skills is seen as a rational choice in time-preference, deferring current gratification in exchange for anticipated future earnings. The most successful companies and the most successful countries will be those that manage human capital in the most effective and efficient fashion by investing in their workers, encouraging workers to invest in themselves, providing a good learning environment including social capital as well as skills and training (Becker, 2002).

Human capital theory, introduced in 1964 by Gary Becker, makes a very simple argument: investments in education-either formal or informal - increase an individual's level of productivity and therefore improve their earnings potential (Gattiker, 1995). Although we may not know it, nearly every individual and organization have or will make a decision based on this theory. 


\section{Resource-based Perspective}

The resource-based perspective is based on the assumption that differences in physical, organizational and HR between firms cause a fundamental heterogeneity in their productive potential. Given this heterogeneity, the long-term competitiveness of a company depends upon the resources that not only differentiate it from its competitors, but are also durable and difficult to imitate and substitute (Hansen and Wernerfelt, 1989; Mahoney and Pandian, 1992; Barney, 1991; Prahalad and Hamel, 1990; Rangone, 1999). HR is an important source to generate sustained competitive advantage: "human resource systems can contribute to sustained competitive advantage through facilitating the development of competencies that are firmspecific and generate tacit organizational knowledge" (Lado and Wilson, 1994). Maintaining a competitive advantage based on HR requires management of those HR that ascertains that these resources stay competitive, difficult to imitate and to substitute. The resource-based approach stresses the need for a specific HRM strategy, which seeks to achieve competitive advantage by increasing commitment and competence of the workforce. This would require a set of internally consistent HRM practices, or, in other words, an internal fit of HRM practices. Obtaining internal fit is often associated with a best-practice approach to HRM practices (Huselid, 1995; Legge, 1995). The "best practices" or "high-commitment" theory of HRM suggests that universally, certain HRM practices (bundles of practices) are associated with improved organizational performance.

\section{Behavioral Perspective}

The behavioral perspective on HRM can be defined as the use of personnel practices as tools for shaping patterns of behavior that help to achieve organizational goals and objectives (Naylor et al.,1980). Different goals and objectives require different strategies and behaviors, and therefore, different HRM practices (Snell, 1992). This leads to a focus on an external fit, resulting in contingency theories on HRM (Huselid, 1995; Legge, 1995). Size, technology, ownership, sector and location are examples of contingency variables that have been included in previous studies (Delery and Doty, 1996).

Barney and Hesterley (1996) note that empirical support of the hypotheses laid out by the behavioral perspective are relatively weak. Nevertheless, the argument of fitting strategy and HRM practices is compelling. Rather than look at generic strategies and HRM practices, a different group of researchers posit a link between growth oriented strategies and greater emphasis on HRM. In sum, although it is not clear that the generic strategies as defined by Porter require different sets of HRM practices, there may well be some correlation between aspects of strategy such as growth orientation and the HRM practices that evolve.

\section{Ability-Motivation-Opportunity (AMO) Model}

Most research in the past two decades has portrayed an HR system as an additive index of a set of individual HR practices (Combs et al., 2006). Taking a different approach, some researchers have drawn upon the ability-motivation-opportunity (AMO) model of HRM and suggested that employee performance is a function of three essential components: ability, motivation, and opportunity to perform (Jiang et al. 2012). HR systems designed to maximize employee performance can be viewed as a composition of three dimensions intended to enhance employee skills, motivation, and opportunity to contribute, respectively (Boxalland Purcell, 2008; Gerhart, 2007; Lepak et al., 2006). 
Lepaket al. (2006) suggested that it might be fruitful to conceptualize HR practices as falling into one of three primary dimensions: skill-enhancing HR practices, motivation-enhancing HR practices, and opportunity-enhancing HR practices. Skill enhancing HR practices are designed to ensure appropriately skilled employees; they include comprehensive recruitment, rigorous selection, and extensive training. Motivation-enhancing $\boldsymbol{H R}$ practices are implemented to enhance employee motivation. Typical ones include developmental performance management, competitive compensation, incentives and rewards, extensive benefits, promotion and career development, and job security. Opportunity-enhancing HR practices are designed to empower employees to use their skills and motivation to achieve organizational objectives. Practices such as flexible job design, work teams, employee involvement, and information sharing are generally used to offer these opportunities. The use of the three dimensions of HR systems instead of a one-dimensional or two-dimensional framework is based on an examination of differential effects of the three dimensions of HR systems on different types of HR outcomes (Jiang et al., 2012).

\section{HRM dimensions and HR outcomes}

\section{A Theoretical Model for Tourism Sector}

Based on AMO model, HR outcomes can conceptually be divided into human capital, motivation, and opportunity to contribute (Becker and Huselid, 1998; Delery and Shaw, 2001; Guest, 1997), and human capital and employee motivation are two of the most critical mediating factors that have been examined in the literature (e.g., Gardner et al., 2011; Gong et al., 2009; Liao et al., 2009; Sun et al., 2007; Takeuchi et al., 2007; Youndt and Snell, 2004). There is still paucity of research that has examined the mediating effect of "opportunity to perform". Although, overwhelm of literature has mainly focused on the mediating roles of human capital and employee motivation still one can assume a mediating effect of opportunity to perform. It can be anticipated that all three HR dimensions are positively related to all three dimensions of HRM outcomes; human capital, employee motivation, and opportunity to perform. But these three HR dimensions may play different roles in building human capital, enhancing employee motivation, and increasing opportunities to perform.

\section{Proposed HRM-Business Performance Model}

Drawing upon the behavioral perspective of HRM, human capital theory, and the resource based view of the firm, in sum, a mediating model in which the three dimensions of HR systems are indirectly related to business performance through human capital, employee motivation, opportunity to perform and HR outcomes in sequence is proposed. The proposed model can be depicted as shown in Figure 1. In building this framework, it is focused on the mediating role of employees in the link of HRM with business performance. 
Figure 1: Theoretical Model of the impact of HR Dimensions on Business Performance

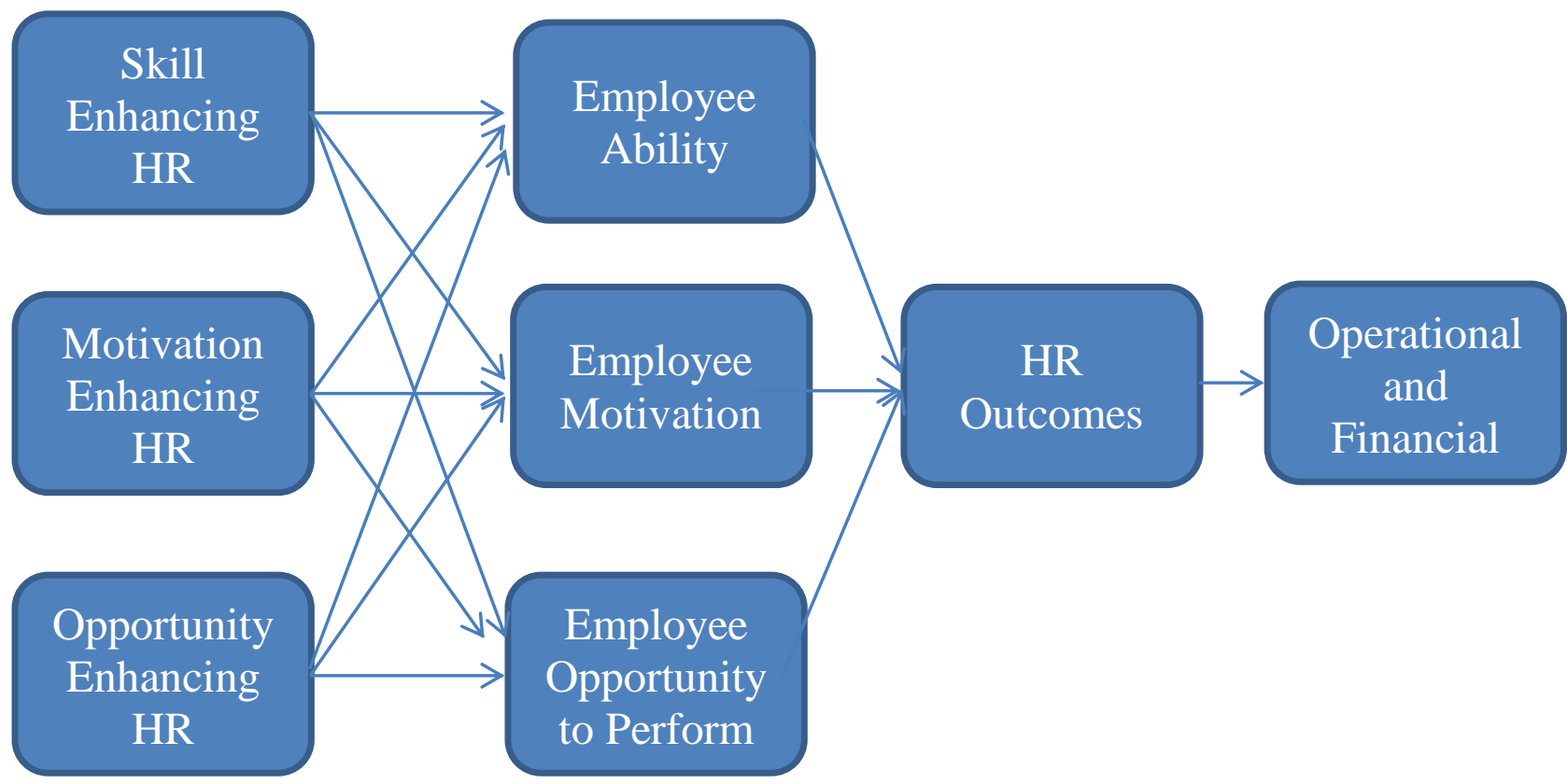

Source: Constructed by the Author, 2016

According to the proposed model, first three dimensions of HR practices - ability enhancing, motivation enhancing and opportunity enhancing - will make an impact on human capital, motivation, and opportunity to perform of employees at varying degrees. Human capital and opportunity to perform also will have links with employee motivation thereby making an impact on motivation. All these three mediating variable will have direct impact on both employee intention to leave and HR outcomes and indirect impact on operational and financial outcomes. Employee intention to leave is the employee propensity to leave the organization in the near future. The decision to leave the organization will incur cost to the firm. However, through effective implementation of so called three dimensional HR practices will reduce the propensity to leave the organization through increased motivation, human capital and opportunity to perform. Therefore, a direct relationship between HR outcomes - increased ability, motivation, and opportunity to perform - and intention to leave is expected. Moreover, increased ability, motivation and opportunity to perform will make a direct impact on operational and financial outcomes of the firm.

\section{Implication of the Research}

This study offers methodological implications for researchers studying in HRM practices on business performance on tourism industry in Sri Lanka. According to the proposed model, all three dimensions of HR systems will have unique effects on HR outcomes. Therefore, it is imperative to include all the three dimensions of HRM practices in their studies and failure to include any dimension may compromise the overall impact of HR systems on HR outcomes. Therefore, it is highly recommended to include all three dimensions in studies when examining the impact of HRM on business performance. As practical implications of the study, firms and 
their managers in tourism industry will be able to focus more on the human side of business management in order to improve their business performance. Based on the model one can embark on a study not only to examine the impact of HRM practices on business performance, but also to understand the process through which these impacts will occur. In short, the proposed model will be helpful to understand the so called Black Box or the missing link of the HRMbusiness performance paradox.

\section{References}

Barney, J. B. (1991), Firm Resource and Sustained Competitive Advantages, Journal of Management, Vol. 17, No. 1, pp. 99-120.

Barney, J. B., and Hesterly, W. (1996), Organizational economics: Understanding the relationship between organizations and economic analysis. In Clegg, S. R, Hardy, C. and W. R. Nord (Eds.), Handbook of Organization Studies, London: Sage Publications.

Becker, S. G. (2002), Talking human capital with Gary Becker, Nobel laureate. Retrieved from http://www.linezine.com/4.1/interviews/gbbmthc., accessed on 1/12/2015.

Becker, S. G. (1964), Human capital: a theoretical and empirical analysis, with special reference to education, National Bureau of Economic Research: Columbia U.P.

Becker, B. E., and Huselid, M. A. (1998), High performance work systems and firm performance: A synthesis of research and managerial implications. In G. R. Ferris (Ed.), Research in personnel and human resources management: pp.53-101. Greenwich, CT: JAI Press.

Boxall, P., and Purcell, J. (2008), Strategy and human resource management. Basingstoke, U.K: Palgrave Macmillan.

Capital Alliance (2015), Sri Lanka Tourism Sector Summary Overview 2011-2020, Retrieved from http://www.capitalalliance.lk/weekly/other/SLtourismsectoroverview20112020.pdf(access on 1/12/2015).

Christopher J. C., Jeff E., and Mathew A. (2005), Employee Outcomes: Human Resource Management Practices and Firm Performance in Small Businesses, Research Report On Phase 3 of the Cornell University/Gevity Institute Study, Available at http://digitalcommons.ilr.cornell.edu/cgi/viewcontent.cgi?article=1486\&context=cahrswp, (accessed on 11/10/2016).

Combs, J., Liu, Y., Hall, A., and Ketchen, D. (2006), How much do high-performance work practices matter? A meta-analysis of their effects on organizational performance. Personnel Psychology, Vol.59, pp. 501-528.

Delery, J. E. and Dotty, H.D. (1996), Modes of theorizing in strategic human resource management: Tests of universalistic, contingency and configurational performance predictions, Academy of Management Journal, Vol. 39, No. 4, pp. 802-835.

Delery, J. E., and Shaw, J. D. (2001), The strategic management of people in work organizations:

Review, synthesis, and extension. In G. R. Ferris (Ed.), Research in personnel and human resource management, Vol. 20, pp. 167-197.

Dessler, G. (2008). Human Resource Management, 11th ed., NJ: Pearson Prentice-Hall, Upper Saddle River.

Dyer, L., and Reeves, T. (1995), Human resource strategies and firm performance: What do we know and where do we need to go? International Journal of Human Resource Management, Vol. 6, pp. 656-670. 
Fisher, C.D. Schoenfeldt, L.F. and Shaw, J.B. (2006), Human Resource Management, 6th ed., Boston, MA: Houghton Mifflin.

Flangan D. S. and Despande, S. P. (1996), Top management's perceptions of changes in HRM practices after union elections in small firms, Journal of Small Business Management, Vol. 34, No. 4, pp. 23-34.

Gardner, T. M., Wright, P. M., and Moynihan, L. M. (2011), The impact of motivation, empowerment, and skill enhancing practices on aggregate voluntary turnover: The mediating effect of collective affective commitment. Personal Psychology, Vol. 64, pp. $315-350$.

Gattiker, U. E. (1995), Firm and taxpayer returns from training of semiskilled employees. Academy of Management Journal. Vol. 38, No. 3, pp.1152-1173.

Gerhart, B. (2007), Horizontal and vertical fit in human resource systems. In C. Ostroff and T. A. Judge (Eds.), Perspectives on organizational fit: pp. 317-348. New York: Psychology Press.

Gong, Y., Law, K. S., Chang, S., and Xin, K. R. (2009), Human resources management and firm performance: The differential role of managerial affective and continuance commitment. Journal of Applied Psychology, Vol. 94, pp. 263-275.

Guest, D. E. (1997), Human resource management and performance: A review and research agenda. International Journal of Human Resource Management, Vol. 8, pp. 263-276.

Hansen, G. S. and Wernerfelt, B. (1989), Determinants of firm performance: The relative importance of economic and organizational factors. Strategic Management Journal, Vol. 10, pp. 399-411.

Huselid, A. M. (1995), The impact of human resource management practices on turnover, productivity and corporate financial performance. Academy of Management Journal, 38 (3): 635-672.

Jiang. K. and Lepak, (2012), How does Human Resource Management influence organizational outcomes? A Meta- analytical investigation mechanism. Academy of Management Journal Vol. 55, No. 6, pp. 1264-1294.

Kelegama, S (2014), Key challenges facing the tourism sector in Sri Lanka, Daily FT, Retrieved from http://www.ft.lk/2014/06/27/key-challenges-facing-the-tourism-sector-in-sri-lanka/, (accessed on 30/12/2015).

Lado, A .A. and Wilson, M. C. (1994), Human resource systems and sustained competitive advantage: A competency based perspective. Academy of Management Review, Vol.19, pp. 699-727.

Legge, K. (1995), Human Resource Management; Rhetorics and Realities. London: Macmillan Business.

Lepak, D. P., Liao, H., Chung, Y., and Harden, E. E. (2006), A conceptual review of human resource management systems in strategic human resource management research. In J. J. Martocchio (Ed.), Research in personnel and human resource management, Vol. 25, pp. 217-271.

Liao, H., Toya, K., Lepak, D. P., and Hong, Y. (2009), Do they see eye to eye? Management and employee perspectives of high-performance work systems and influence processes on service quality, Journal of Applied Psychology, Vol. 94, pp. 371-391.

Mathis, R., and Jakson, J. (1991), Personnel/Human resource management, 6th ed. St Paul, Minn: West Publishing.

McEvoy, M. G. (1984), Small business personnel practices. Journal of Small Business Management, Vol. 22, No. 4, pp. 1-8. 
Naylor, J. C., Pritchard, R.D., and Ilgen, D.R. (1980),A Theory of Behavior in Organizations, New York: Academic Press.

Opatha, H.H.D.N.P. (2009). Human resource management, Colombo: Author published.

Pfeffer, J. (1994), Competitive advantage through people: unleashing the power of the workforce, Harvard Business School press: Boston.

Prahalad, C.K. (1983), Developing strategic capability: An agenda for top management. Human Resource Management, Vol. 22, No. 3, pp. 237-254.

Prahalad C.K. and Hamel Gary (1990), The Core Competence of the Corporation, Harvard Business Review, May-June: pp. 79-90.

Rangone, A., (1999), A resource-based approach to strategy analysis in small-medium sized enterprises. Small Business Economics, Vol. 12, pp. 233-248.

Shamali M.M.M. and Smarakoon S.M.A.K. (2010), Human Resource Management Practices in the Hotel Industry in Sri Lanka, Conference Proceeding, International Conference in HRM, University of Kelaniya.

Snell, S.A.(1992),Control theory in strategic human resource management: The mediating effect of administrative information. Academy of Management Journal, Vol. 35, No.2, pp. 292327.

Srilal, M. (2014), Sri Lanaka Tourism 2013, Daily FT: Retrieved from http://www.ft.lk/2014/01/29/a-look-back-at-sri-lanka-tourism-2013-the-good-the-bad-andthe-ugly (accessed on 30/04/2015).

Stone, R. J. (2005). Human Resource Management, 5th ed., Australia: John Wiley \& Sons.

Sun, L. Y., Aryee, S., and Law, K. S. (2007), High performance human resource practices, citizenship behavior, and organizational performance: A relational perspective. Academy of Management Journal, Vol. 50, pp. 558-577.

Takeuchi, R., Lepak, D. P., Wang, H., and Takeuchi, K. (2007),An empirical examination of the mechanisms mediating between high-performance work systems and the performance of Japanese organizations. Journal of Applied Psychology, Vol. 92, pp. 1069-1083.

Terpstra, E. D., and Rozell, J. E. (1993), The relationship of staffing practices to organizational level measures of performance Personnel Psychology, Vol. 46, No.1, pp. 27-48.

WTTC (2015), Travel and Tourism: Economic Impact, World Travel and Tourism Council Retrievedfromhttp://www.wttc.org//media/files/reports/economic\%20impact\%20research/regional\%20reports/world2014.pdf (accessed on 30/12/2015).

Youndt, M. A., and Snell, S. A. (2004), Human resource configurations, intellectual capital, and organizational performance. Journal of Managerial Issues, Vol. 16, pp. 337-360. 